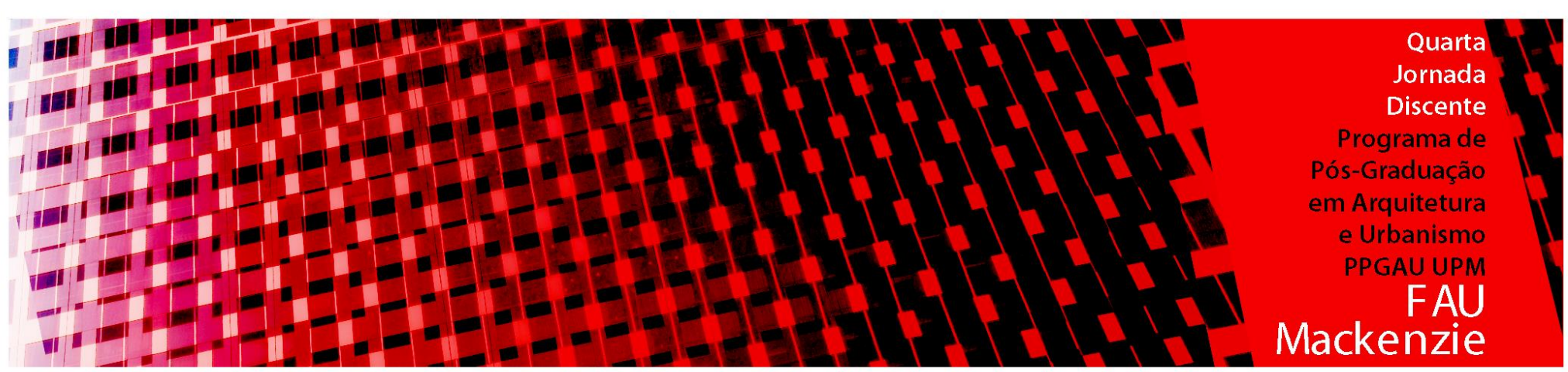

\title{
As Arenas Esportivas e as Metrópoles: As Análises Urbanas dos Estádios de Brasília, Curitiba e Recife para a Copa do Mundo FIFA 2014
}

The Sportive Arenas and the Metropoles: The Urban Analysis of the Stadiums of Brasilia, Curitiba and Recife for the 2014 FIFA World Cup

\section{Thiago Vidal Pelakauskas ${ }^{1}$, Prof. ${ }^{a}$ Dr $^{\mathrm{a}}$ Eunice Helena Sguizzardi Abascal ${ }^{2}$}

${ }^{1}$ Faculdade de Arquitetura e Urbanismo da Universidade Presbiteriana Mackenzie, São Paulo, Brasil, arq.thiagovp@gmail.com

2 Professora Doutora, Faculdade de Arquitetura e Urbanismo da Universidade Presbiteriana Mackenzie, eunicehab@gmail.com 


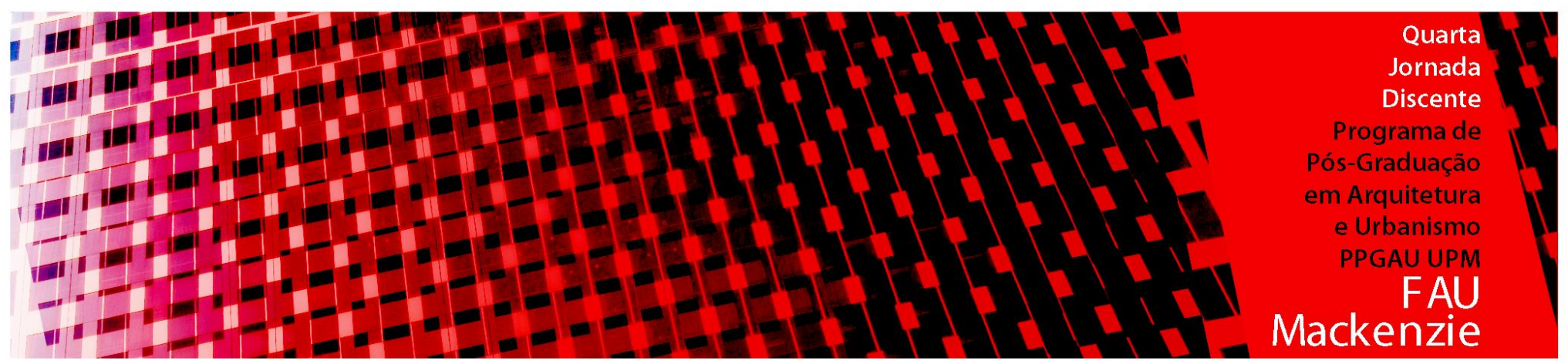

\title{
RESUMO
}

O objeto de estudo do presente trabalho refere-se aos estádios construídos no Brasil nesta última década, edifícios estes, que trazem consigo a monumentalidade da cidade espetáculo (ARANTES, 2000). A espetacularização vem sendo considerada uma justificativa usada como instrumento para uma intervenção urbana ad hoc (ASCHER, 2001), na forma de estádios em áreas urbanas em sua maioria periféricas, localizadas no âmbito da metrópole, citando como exemplo, o programa requerido para sediar a Copa do Mundo FIFA. São estádios, potencialmente projetados para uso múltiplo, podendo durar um curto espaço de tempo como partidas de futebol, shows e eventos, gerando assim, como argumentam os defensores destes investimentos, um dos supostos "legados" para a cidade em questão. Diversas cidades brasileiras, realizaram inúmeros projetos urbanos, desde a complementação dos sistemas de transportes até a construção de novos equipamentos públicos. Contudo, para que se possa discutir os impactos provenientes destas intervenções urbanísticas e arquitetônicas, este trabalho analisará este fenômeno contemporâneo por meio do estudo de alguns estádios construídos para a Copa do Mundo FIFA 2014, como por exemplo a Arena da Baixada (Curitiba), o Estádio Mané Garrincha (Brasília) e a Arena Pernambuco (Recife) em sua escala urbana.

Palavras-chave: Estádios, Arenas, Copa do Mundo, Urbanismo, Metrópoles.

\begin{abstract}
The object of study of the present work refers to the stadiums constructed in Brazil in the last decade, these buildings, which bring with it the monumentality of the spectacle city (ARANTES, 2000). Spectacularization has been considered a justification used as an instrument for an ad hoc urban intervention (ASCHER, 2001), in the form of stadiums in mostly peripheral urban areas, located in the metropolis, citing as an example the program required to host the FIFA World cup. They are stadiums, potentially designed for multiple uses, and can last a short time, such as football matches, shows and events, thus generating, as the defenders of these investments argue, one of the supposed "legacies" for the city in question. Several Brazilian cities have carried out innumerable urban projects, from the complementation of transportation systems to the construction of new public facilities. However, in order to discuss the impacts of these urban and architectural interventions, this work will analyze this contemporary phenomenon through the study of some stadiums built for the 2014 FIFA World Cup, such as the Arena da Baixada (Curitiba), the Mané Garrincha Stadium (Brasília) and the Arena Pernambuco (Recife) in its urban scale.
\end{abstract}

Key-words: Stadiums, Arenas, Word Cup, Urbanism, Metropoles. 


\section{INTRODUÇÃ̃O}

As cidades brasileiras acabaram realizando na última década uma empreitada, em escala até então nunca antes vista, no que se refere a construção de estádios e ginásios para sediar respectivamente a Copa do Mundo e os Jogos Olímpicos. Nesta parte do trabalho, serão discutidos e analisados os projetos de três estádios utilizados na Copa do Mundo de 2014. Localizados em três regiões do país e com contextos sócio urbano e econômicos diferenciados, os estádios de Curitiba, de Brasília e de Recife foram escolhidos para esta análise. Em primeiro lugar, o estádio particular do Atlético Paranaense, a Arena da Baixada em Curitiba, projeto de reforma executado pelo arquiteto uruguaio Carlos Arcos (no estudo de concepção em parceira com o arquiteto Hector Vigliecca) em segundo, o novo estádio público Nacional Mané Garrincha, em Brasília, projeto de autoria do escritório Castro Mello Arquitetos e por último o novo estádio formatado em parceria público privada (PPP), a Arena Pernambuco, em São Lourenço da Mata (Região Metropolitana de Recife) projetado pelo escritório Fernandes Arquitetos Associados.

Enquanto o estádio paranaense, propriedade particular e de capital privado, encontra se em uma área urbana consolidada, cercado por edifícios comerciais e residenciais que acabam limitando a sua expansão horizontal, os outros dois casos estudados acabam se apresentando de maneira antagônica, tanto urbanisticamente quanto economicamente. O estádio brasiliense presente no eixo monumental do plano piloto, como será discutido, possui uma ampla área em seu entorno e devido a sua nova arquitetura acabou se caracterizando como mais um dos palácios presentes no eixo monumental alterando assim a paisagem em seu entorno. Já o recente novo estádio pernambucano, foi construído na região metropolitana de Recife, uma cidade que já dotava de três estádios para os seus respectivos clubes, seguindo as tendências de utilização de um equipamento de escala urbana como elemento indutor de desenvolvimento de novos bairros.

Enquanto a Arena da Baixada consegue se manter com a realização de jogos de futebol do Atlético Paranaense e outros tipos de eventos, os dois estádios, Mané Garrincha e a Arena Pernambuco, buscam encontrar soluções e alternativas para conseguirem se manter vivos e operantes. A partir de matérias da mídia local, textos específicos sobre o assunto, gráficos analíticos desenvolvidos e fotos obtidas durante visitas in loco, este trabalho tem como objetivo demonstrar as estratégias projetuais e as consequências, sucessos ou insucessos, da implantação destes edifícios de escala metropolitana, em seus respectivos tecidos urbanos.

\section{ARQUITETURA DO ESPETÁCULO NA PELE URBANA}

As cidades contemporâneas tem se utilizado do artifício da construção e execução de equipamentos âncora, normalmente a serem inseridos em áreas periféricas ou centrais com vocação de revitalização (antigas áreas industrias ou portuárias), como por exemplo, a construção de novos museus e centro culturais, edifícios multifuncionais, estações intermodais de transporte público e equipamentos esportivos como estádios e ginásios, afim de que a instalação destes equipamentos em uma trama urbana possa gerar um efeito denominado de "acupuntura urbana" (SOLÀMORALES, 2008, p. 24), no qual se espera como resultado a médio longo prazo no desenvolvimento local da região em questão. Entendendo se que "a pele das cidades é feita de construções, texturas, contrastes" e "de ruas e espaços livres, de jardins e muros, de perfis e vazios" (SOLÀ-MORALES, 2008, p. 23), pode ser colocado a respeito do efeito da acupuntura urbana:

\footnotetext{
“Como na acupuntura terapêutica, a localização do ponto sensível é o primeiro passo para o tratamento estratégico da pele urbana. O sucesso na identificação do local e dos canais de influência no tecido permitirá contribuir com uma nova qualidade, para agregar a energia adequada, fria ou quente, para promover a urbanidade em suas diversas formas.
} 
[...] A acupuntura tem a ver especialmente com uma apreciação muito superior da epiderme como uma membrana rica, complexa e enormemente influente.

[...] Intervir na pele da cidade, portanto, tem uma certa analogia com a ação da acupuntura. Não pelo uso de agulhas ou pequenas incisões, mas pela compreensão da natureza sistêmica da epiderme.

A epiderme dos tecidos urbanos nos permite transformar os metabolismos internos do organismo que, no abstrato, outros expressam em termos socioeconômicos, simbólico-culturais, infra estruturais ou histórico-políticos." (SOLÀ-MORALES, 2008, p. 24-25)

Sendo assim, colocado este conceito de "pele urbana" acima, os elementos de escala metropolitana a serem analisados serão os estádios. Estes tipos de edifícios carregam consigo o significado de serem equipamentos de concentração das "massas", "pontos de encontro" (WILHEIM, 1963, p. 295) entre os torcedores provenientes de várias partes de uma cidade, onde todos ali podem desfrutar de momentos de comunhão e celebração do evento esportivo ou de algum outro tipo de evento artístico ou até mesmo religioso. Por possuírem esta escala, os estádios contemporâneos projetados pelo mundo afora, buscam algo além de serem somente edifícios que contemplam o seu uso primordial esportivo, também almejam se tornarem "monumentos" dotados de um capital simbólico que acaba por si só denotando uma arquitetura do espetáculo, conforme aponta David Harvey (2001, p. 68), ao questionar a estratégias que as cidades contemporâneas, principalmente as localizadas em países de economia emergente, tem se utilizado para a revitalização de tramas urbanas específicas, utilizando se da inserção de equipamentos urbanos, como por exemplos os estádios, para a ativação do desenvolvimento local:

\footnotetext{
"Quantos centros de convenções, estádios, Disney Worlds, zonas portuárias renovadas e shopping centers espetaculares podem existir? Muitas vezes, o sucesso é fugaz ou se torna discutível pelas novidades semelhantes ou alternativas que surgem em outros lugares.

[...] A ênfase no turismo, na produção e no consumo de espetáculos, na promoção de eventos efêmeros num determinado palco, mostra todos os sinais de ser o remédio predileto para economias urbanas enfermas.

[...] Os projetos especulativos desse tipo são parte de um problema macroeconômico mais genérico. Em outras palavras, shopping centers e estádios esportivos financiados a crédito, assim como outras facetas do consumo conspícuo, são projetos de alto risco, que podem, com facilidade, defrontar-se com tempos difíceis, exacerbando, como a "supershoppingcenterização da América" dramaticamente ilustra (GREEN, 1998), os problemas da superacumulação e do excesso de investimento, aos quais o capitalismo, como um todo, está tão facilmente propenso." (HARVEY, 2001, p. 68)
}

Portanto, apontado os conceitos teóricos acima, será demonstrado através dos estudos de caso selecionados para este trabalho, a experiência que algumas das cidades brasileiras, que receberam o evento da Copa do Mundo FIFA de 2014, acabaram sofrendo principalmente durante o período de 2009 a 2014, quando diversos projetos urbanos infra estruturais (vias, viadutos, transporte público, etc..) acabaram sendo realizados e de fato pouco realmente executados, além de propriamente os equipamentos esportivos de suporte ao programa do evento, no caso os objetos de análise: os estádios de futebol.

\section{OS ESTÁDIOS}

\subsection{Arena da Baixada, Curitiba}




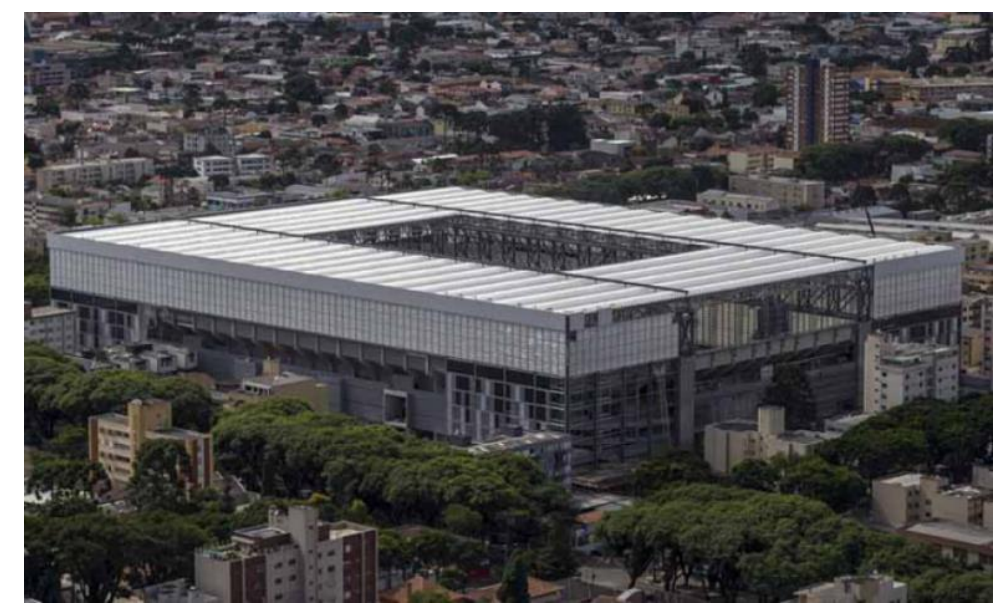

Figura 1: Estádio Joaquim Américo, também chamado de Arena da Baixada, em Curitiba Fonte: Site Jornal Lance, sem data.

Uma das doze sedes da Copa do Mundo FIFA 2014, a cidade de Curitiba, utilizou o estádio existente Joaquim Américo Guimarães, mais conhecido como a Arena da Baixada, para receber as quatro partidas do evento, sendo todas na fase de grupos. Localizado, no bairro Água Verde, próximo ao centro da cidade, em uma área de predomínio de gabarito horizontal e de uso misto, o estádio está implantado fora do alinhamento do eixo norte sul porém, o seu entorno não possibilita esta locação recomendada pela FIFA, uma vez que as residências e os outros tipos de edifícios comerciais adjacentes já delimitavam o seu espaço de expansão.

Dentro deste contexto, a Arena da Baixada, assemelhasse ao que se refere em sua implantação e ao seu contexto urbano ao Estádio do Bessa Século XXI (2003 - Grupo3 Arquitectura) localizado em Porto, Portugal, ao Estádio Luigi Ferraris (Reformado em 1989 - Vittorio Gregotti), em Gênova, Itália e no cenário nacional, ao Estádio da Vila Belmiro na cidade de Santos. Estes estádios que possuem a sua geometria retangular e implantados em áreas com gabarito de predomínio horizontal, onde suas referidas testadas não apresentam, na maioria de suas fachadas, um recuo generoso em relação à rua, portanto fazendo com que o estádio faça das ruas circundantes a sua praça "temporária". Como coloca Mauro Calliari (2014), em seu artigo "O melhor estádio do Brasil combina futebol e urbanidade", a Arena da Baixada, traz uma "grata surpresa: o estádio conversa com a cidade." De fato, como colocado anteriormente, este é um estádio que a contrário dos outros exemplos estudados neste trabalho, possui uma conexão direta com o seu entorno imediato mas, a sua escala perante ao seu contexto urbano faz com que o estádio acabe se destacando na paisagem.

Este estádio foi construído em 1914 e teve a sua primeira grande reforma em 1999. Foi um dos primeiros no Brasil a utilizar o sistema de naming rights, sendo chamado de Kyocera Arena, nome este abandonado após o término do patrocínio desta empresa com o clube Atlético Paranaense. Nesta configuração, o estádio já apresentava o seu formato retangular com arquibancadas mais próximas ao campo de jogo, sendo o setor da rua Brasílio Itiberê construído aos poucos, devido a presença de uma escola no local. Posteriormente esta escola foi transferida para um novo endereço, possibilitando o "fechamento" e conclusão das arquibancadas ao longo do perímetro do campo. Por muito tempo nesta configuração anterior, a Arena da Baixada foi considerada pela mídia esportiva, exemplar perante aos outros estádios do Brasil.

Para a Copa do Mundo, a sua capacidade foi ampliada para 42.370 espectadores $^{1}$ afim de atender a demanda mínima de público exigido para esta fase da Copa do Mundo, havendo assim a necessidade de mais uma grande nova reforma. Esta última ampliação teve o seu estudo conceitual

\footnotetext{
${ }^{1}$ Capacidade da Arena da Baixada, após a realização da reforma do estádio para a Copa do Mundo de 2014, conforme matéria jornalística da Gazeta do Povo (28/01/2016).
} 
de arquitetura desenvolvido pela parceria entre os escritórios dos arquitetos uruguaios Vigliecca \& Associados e de Carlos Arcos, sendo este último responsável pelo desenvolvimento do anteprojeto e projeto executivo, contando com o apoio aos projetos urbanísticos, do IPPUC (Instituto Planejamento Urbano de Curitiba).

Não foi somente necessário alterar as configurações do estádio existente como também, realizar algumas intervenções urbanísticas em seu entorno imediato. Destacam se dentre estas intervenções, a reforma da praça Alfonso Botelho no setor sul do estádio, a qual possui conexão e relação espacial com o estádio uma vez que, durante os dias de jogos a referida praça é usada como uma área de concentração e dispersão da torcida do Atlético Paranaense. Como podemos verificar nas imagens a seguir, foram instalados mobiliários urbanos no setor sul do estádio reforçando a conexão que o edifício possui com a praça, além do fato de que a largura da rua Buenos Aires entre o estádio e a praça possui uma escala pequena e quase a mesma não interfere na continuidade entre estes dois espaços.

A praça Afonso Botelho contém equipamentos de circulação e permanência, tais como: um pequeno anfiteatro descoberto, que acaba funcionando também como escadaria de acesso entre a cota de nível mais alta e a cota de nível mais baixa da praça, quadras poliesportivas e pistas de skate, favorecendo a função temporária de se tornar uma extensão do estádio no que se refere a um espaço de concentração pré-jogo e dispersão pós jogo.

Continuando a circular no entorno da Arena da Baixada, percebemos na rua Brasílio Itiberê, que o estádio acaba se integrando como um edifício com uso comum, ou seja, a sua espacialidade externa não acaba transmitindo a característica comum de um estádio, com os degraus da arquibancada aparentes como normalmente estes tipos de edifício demonstram em sua fachada, mas sim, um revestimento em chapas metálicas, obedecendo o plano cartesiano, escondendo o seu conteúdo esportivo. Nesta rua encontra se os acessos para o edifício garagem, construído dentro da reforma para a Copa do Mundo, onde a rua Madre Maria dos Anjos termina de fronte ao setor Oeste do estádio, ocasionando uma visão "impactante" onde é perceptível a diferença de escalas e relações espaciais entre o edifício do estádio e as edificações adjacentes, como residências e comerciais.

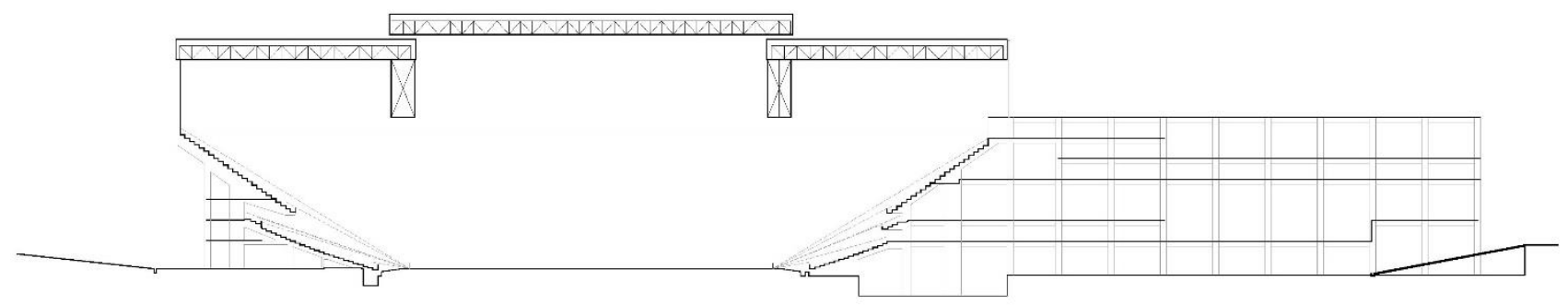

Figura 2: Corte Transversal esquemático da Arena da Baixada. Fonte: Elaborado pelo autor com base no projeto de Carlos Arcos Arquitectura, 2018. 

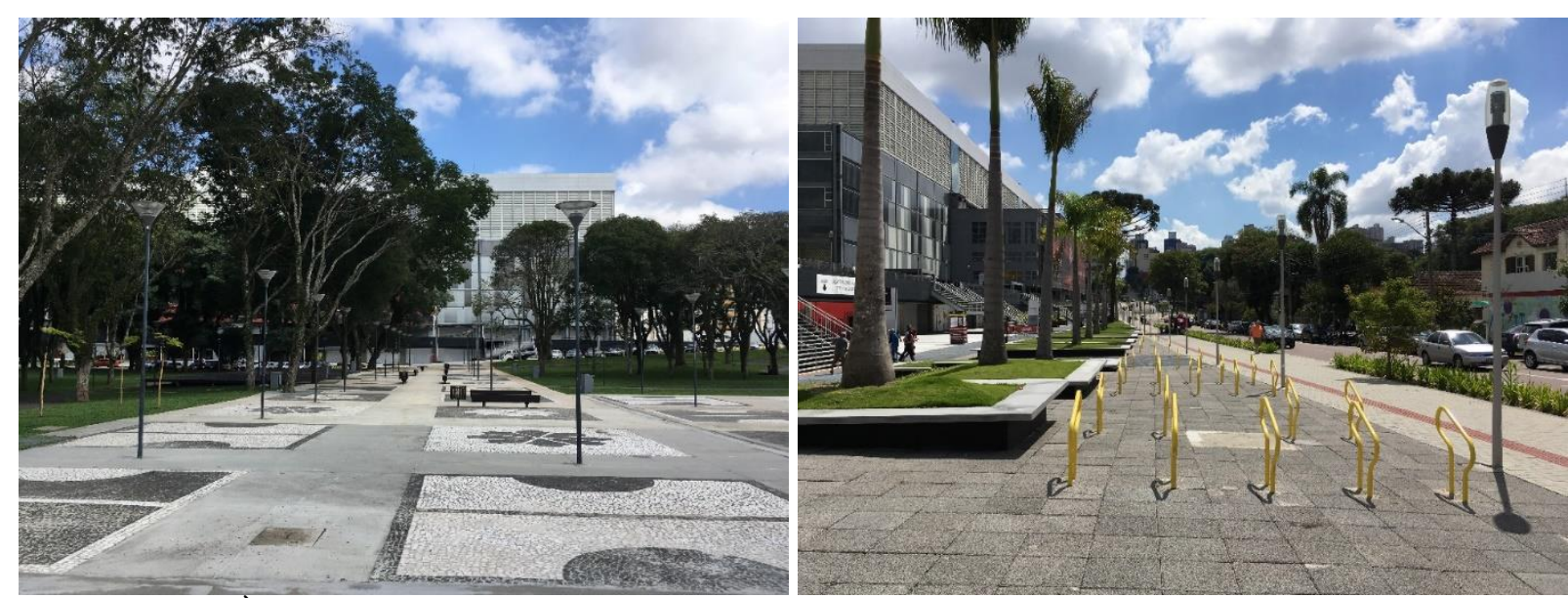

Figuras 3 e 4: À esquerda, vista da praça frontal à Arena da Baixada e à direita, calçamento frontal e mobiliário urbano da Arena da Baixada, em Curitiba.

Fonte: Acervo de Thiago Pelakauskas, 2018.
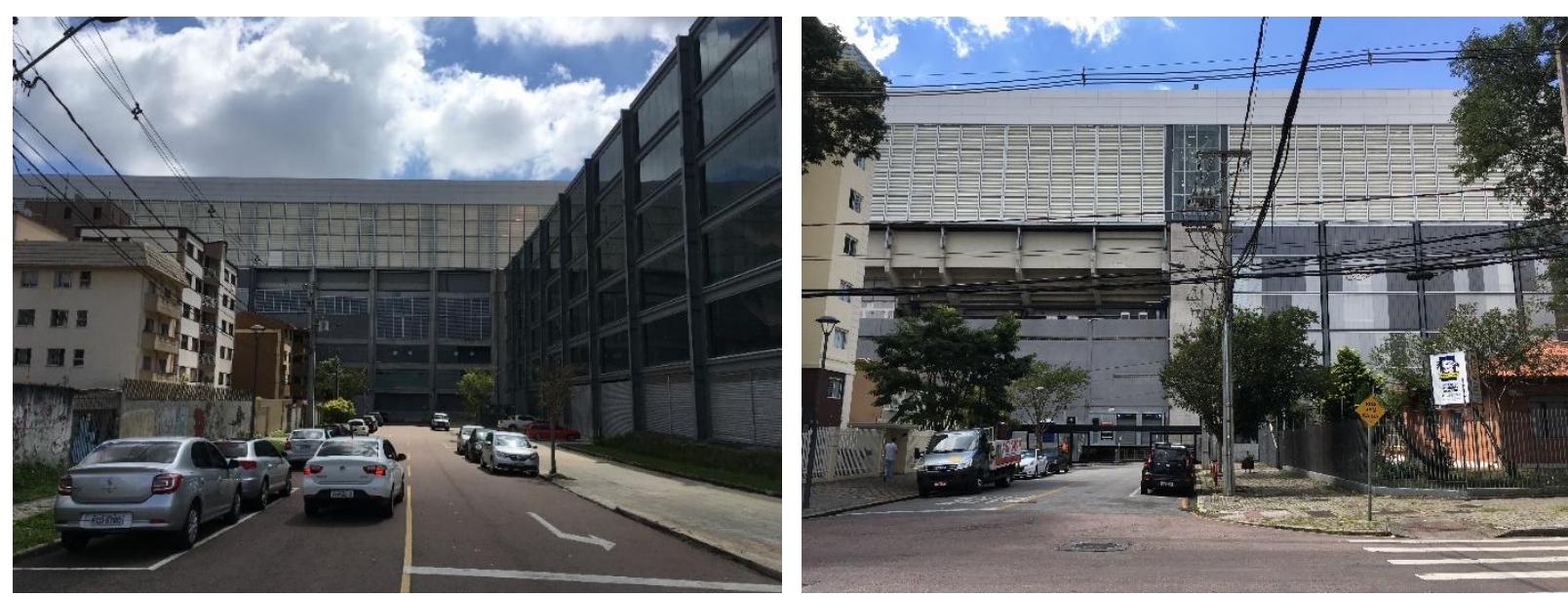

Figuras 5 e 6: Vista da Arena da Baixada a partira da rua Me Maria dos Anjos e da rua Cel Dulcídio, em Curitiba Fonte: Acervo de Thiago Pelakauskas, 2018.

A mesma relação é visível na continuidade da circulação das vias que envolvem o estádio, as ruas Coronel Dulcídio e a avenida Getúlio Vargas, esta última contém uma largura maior do que as demais vias apontadas, uma vez que a mesma possui uma importância na hierarquia viária urbana, por se tratar de uma das vias arteriais da cidade. Curiosamente, esta avenida também possui um outro estádio em sua extensão: o estádio Durival de Brito, construído para a Copa do Mundo de 1950, atualmente utilizado pelo Paraná Futebol Clube. As suas calçadas apresentam se generosas, com um amplo canteiro arborizado e com mobiliário urbano presente, como por exemplo bancos de madeira. Neste setor do estádio temos o acesso de veículos e de torcedores, por um único portão presente entre os edifícios residenciais e comerciais que circundam o estádio.

Para adentrar ao estádio, o visitante necessita acessar a um "nível térreo elevado" presente em um platô descoberto na cota de $5 \mathrm{~m}$, onde o visitante acaba sendo distribuído pelos setores do estádio. As escadas de acesso estão presentes nos quatro setores do estádio. Internamente o estádio se comporta como um espaço multiuso, pois além de sediar as partidas de futebol, sua função principal, e por ser o único estádio $100 \%$ coberto com campo de grama sintética, consegue vários outros tipos de eventos, como por exemplo shows, partidas de vôlei, lutas de $U F C$ e tantas outras atividades esportivas. A cobertura do estádio e o tipo de gramado colaboram para que o estádio consiga de fato ter outros tipos de uso, para gerar receita sem a necessidade fundamental de sediar somente a jogos de futebol. Tais caraterísticas mencionadas, fazem com que operacionalmente não 
haja prejuízo para o estádio, fazendo com que ele seja um dos exemplos de utilização para estádios no Brasil.

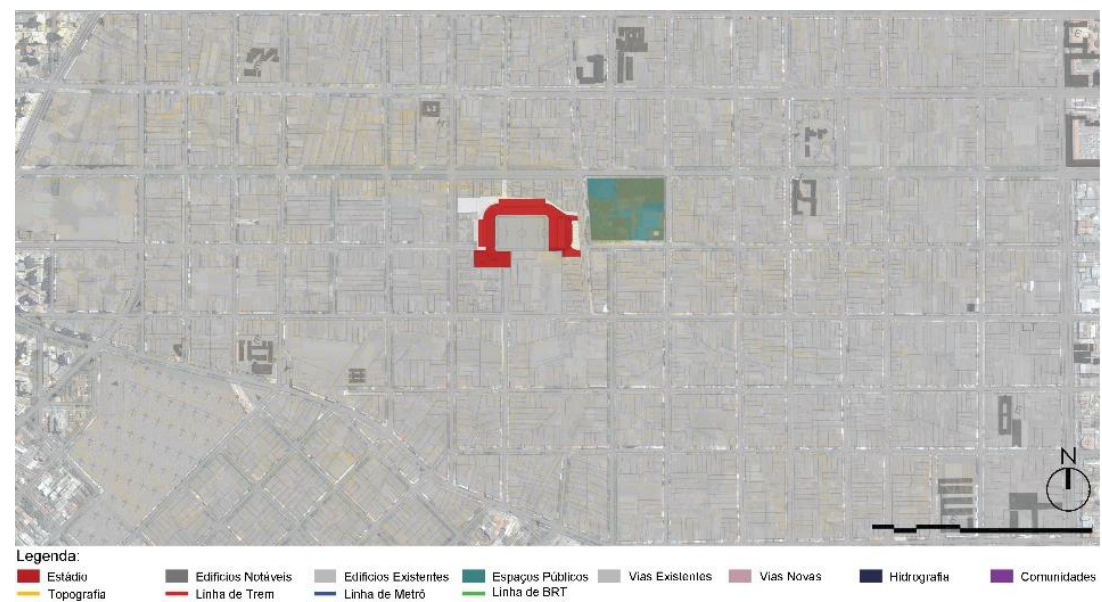

Figura 7: Mapa Urbano do entorno urbano da Arena da Baixada, em Curitiba, em 2010.

Fonte: Elaborado pelo autor, com base no projeto de Carlos Arcos Arquitectura e base cartográfica Google Earth., 2018.

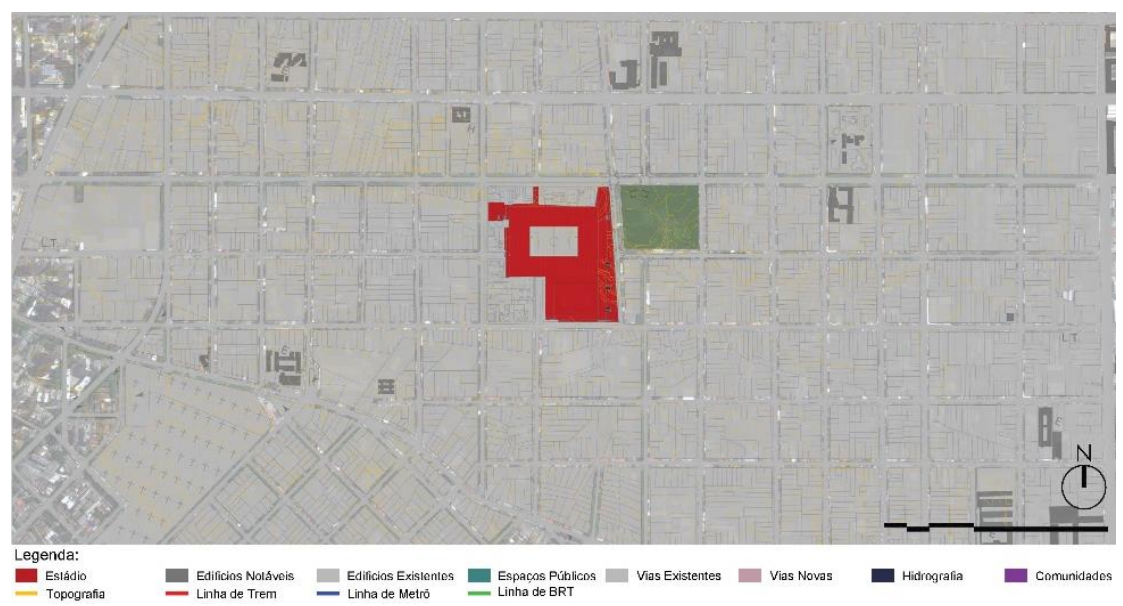

Figura 8: Mapa Urbano do entorno urbano da Arena da Baixada, em Curitiba, em 2014.

Fonte: Elaborado pelo autor, com base no projeto de Carlos Arcos Arquitectura e base cartográfica Google Earth., 2018.

\subsection{Estádio Mané Garrincha, Brasília}

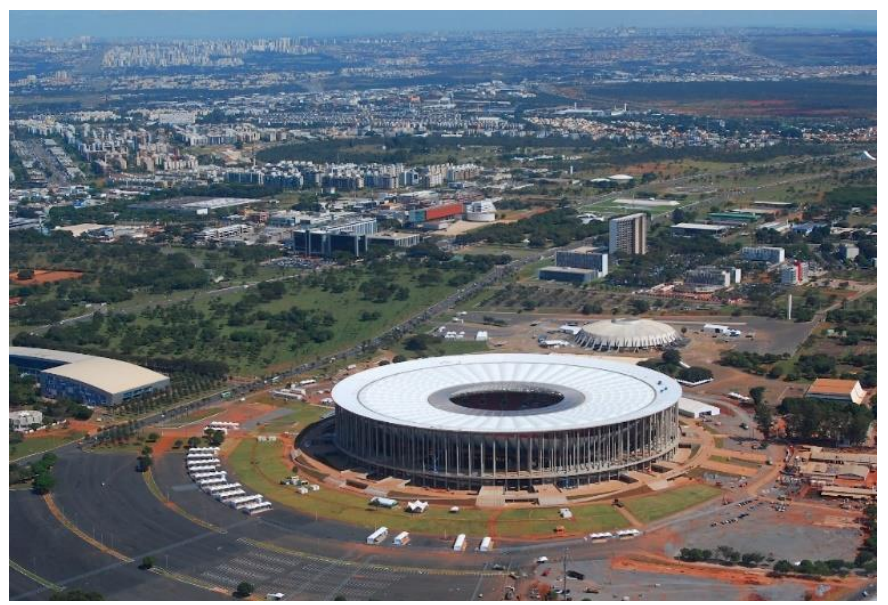


Figura 9: Estádio Mané Garrincha, em Brasília.

Fonte: GDF/Novacap, 2013.

Construído sobre o antigo estádio Mané Garrincha, inaugurado em 1974, tendo o projeto de autoria do arquiteto Ícaro Castro Mello, o novo estádio de Brasília agora chamado de Estádio Nacional Mané Garrincha, teve o seu projeto assinado pelo filho de Ícaro, o arquiteto Eduardo Castro Mello - em parceria com o escritórios alemães GMP Arkhitekten e SBP (Schlaich Bergermam und Partner) - cujo fato denota uma explicação: devido a questão de que o estádio encontra se localizado no eixo monumental de Brasília, cidade tombada pelo patrimônio histórico, a escolha do seu escritório para o desenvolvimento do projeto, se deve, segundo nas palavras do próprio arquiteto: "Os únicos que podem fazer uma intervenção ao longo do eixo monumental de Brasília, eram o próprio Oscar Niemeyer, o Sérgio Bernardes (que fez o centro de convenções e o mastro da bandeira), eu e o meu pai" (Castro Mello, 2014, p. 81). O estádio original possuía a função poliesportiva, com a presença da pista de atletismo entre o campo de jogo e as arquibancadas e a sua capacidade era de aproximadamente 45 mil pessoas e que agora em sua nova versão ampliou sua capacidade para quase 73 mil pessoas.

Estando localizado no eixo monumental de Brasília, além dos emblemáticos Palácios da Justiça, do Itamaraty, o Congresso Nacional e o Conjunto dos Ministérios, todos projetados por Niemeyer, o seu entorno oferecia ao norte o autódromo Nelson Piquet, ao sul o centro de convenções Ulysses Guimarães e a avenida do eixo monumental, à leste o estacionamento de veículos e o setor hoteleiro e pôr fim à oeste, o ginásio Nilson Nelson e o Palácio do Buriti, sede do Governo do Distrito Federal. Portanto os edifícios monumentais projetados por Oscar Niemeyer se tornaram referência e influenciaram na concepção arquitetônica do estádio, principalmente no que se refere à sua fachada composta por 288 pilares com $57 \mathrm{~m}$ de altura. Conforme descreve Eduardo Castro Mello: "Seria um palácio, só que um palácio diferente, um palácio no qual o povo participa" (2014, p. 81). Os pilares acabam sendo "travados" por uma laje presente na cota de acesso à arquibancada superior que por sua vez funciona como uma "varanda" que permite a visualização do espectador visitante à linha do horizonte da cidade de Brasília. Apesar do estádio possuir uma planta circular em sua borda externa e uma planta em formato de elipsóide em seu interior, o fluxo principal dos espectadores acaba acontecendo pelos setores sul, leste e norte pois grande parte da cidade presente no plano piloto está localizada geograficamente abaixo da região do estádio, sendo assim, o setor oeste ficou dedicado para a circulação de atletas, autoridades, convidados e staff.
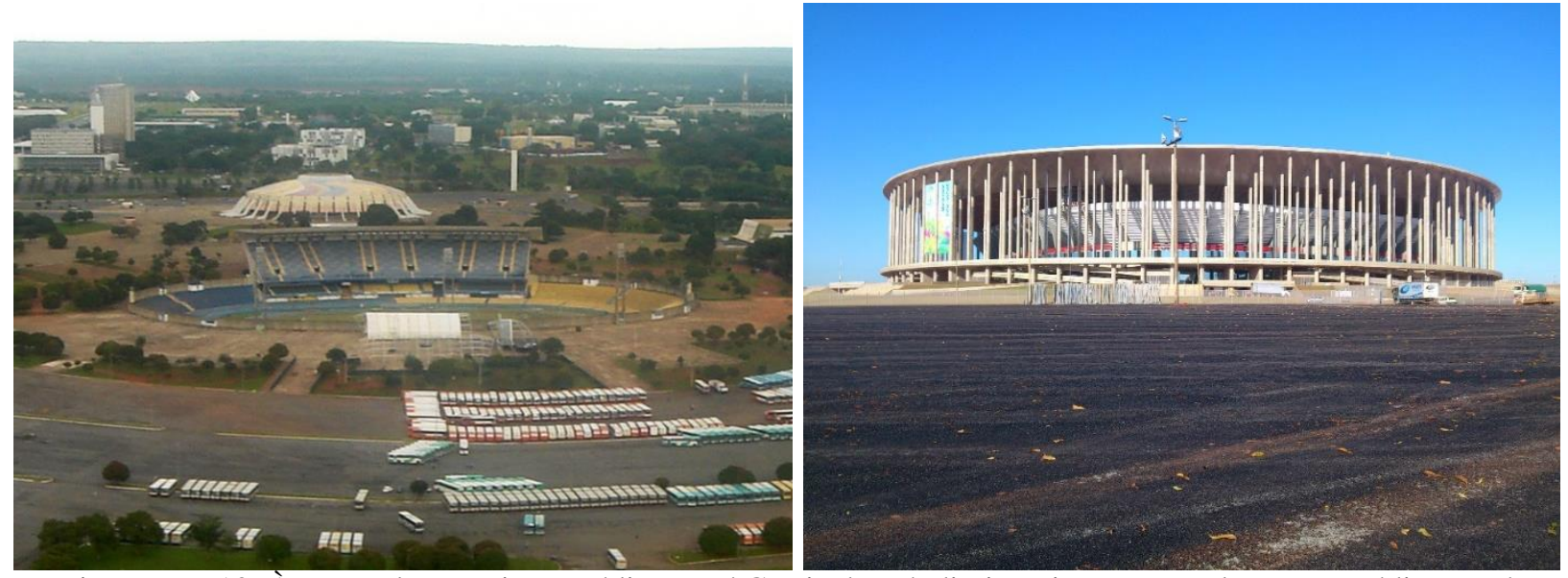

Figuras 9 e 10: À esquerda, o antigo Estádio Mané Garrincha e à direita, vista externa do novo Estádio Mané Garrincha, em Brasília.

Fonte: (FIG9) Mario Roberto Duran Ortiz, 2006 / (FIG10) Thiago Pelakauskas, 2013.

O estádio em sua concepção em planta e corte, acaba apresentando uma das melhores eficiências e desempenho arquitetônico entre os estádios construídos para a Copa do Mundo: sua planta 
permite a circulação, tanto de público como de staff em $360^{\circ}$ em seus níveis principais, facilitando as questões operacionais de acesso e fluxo interno e em corte, a sua curva de visibilidade (em todos os setores) permite uma conformação que acaba configurando a inexistência de pontos cegos na arquibancada. Pela alta inclinação da arquibancada superior, fez se necessário a instalação de guarda corpos de proteção.
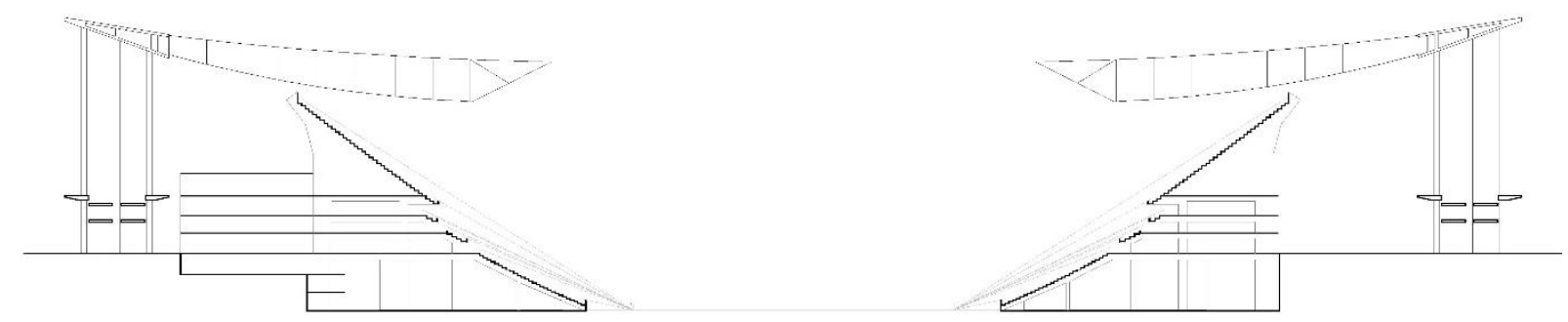

Figura 11: Corte transversal esquemático do Estádio Mané Garrincha.

Fonte: Elaborado pelo autor, com base no projeto de Castro Mello Arquitetos., 2018.

Apesar da cidade de Brasília não possuir nenhum clube na elite do futebol brasileiro ${ }^{2}$, o anseio por parte do governo local em ter um grande estádio, que transmitisse simbolicamente a imagem de poder proveniente da capital federativa do Brasil era intenso, conforme aponta o diretor de Novos Empreendimentos da Terracap ${ }^{3}$, Mário Henrique Lima, em matéria jornalística de 2016: “O Mané Garrincha não foi construído como um negócio, mas como um monumento. É como a Torre Eiffel, o Palácio de Buckingham. Caso contrário não teria sido feito". Portanto isto segue a linha que, conforme Otília Arantes (2000, p.51) aponta, como "desenvolver uma imagem forte e positiva da cidade, explorando ao máximo o seu capital simbólico, de forma a reconquistar sua inserção privilegiada nos circuitos culturais internacionais". Porém entender que o estádio se torne um monumento ou peça imagética de marketing da cidade, acabam por sua vez, estetizando a paisagem urbana, conforme aponta Anne Marie Broudhoux:

\footnotetext{
“Os megaeventos afetam a paisagem urbana, não apenas em que induzem a realização de grandes projetos urbanos e a construção de infraestruturas desportivas, mas também, por que promovem a estetização da paisagem urbana. Isto significa que a visibilidade e a "imaginabilidade" tornam se critérios definidores para orientar as intervenções urbanas e que as ações preocupadas com a imagem são priorizadas, frequentemente em detrimento das necessidades locais mais fundamentais. (2014, p.26)
}

De fato, a diferença de escala do novo estádio em relação ao antigo estádio Mané Garrincha chega a ser abissal: enquanto no antigo estádio, era possível somente visível o único trecho de arquibancada superior construída, sendo que a arquibancada inferior era rebaixada em relação ao nível da rua, neste novo estádio, mesmo com a retirada da pista de atletismo e com o rebaixo de $4,80 \mathrm{~m}$ em relação ao nível do campo de jogo original, para a obtenção de uma melhor curva de visibilidade do espectador ao campo, a volumetria monumental intencional acaba se sobrepondo na paisagem. O estádio integra o complexo esportivo que contém ainda o ginásio Nilson Nelson com capacidade para 16 mil pessoas e o Centro Aquático Cláudio Coutinho. Estes dois equipamentos, construídos na época do estádio original e mantidos até hoje. No projeto original de construção do novo estádio, havia a previsão de um projeto paisagístico do entorno imediato do Mané Garrincha, desenvolvido por Benedito Abbud, que infelizmente não acabou saindo do

${ }^{2}$ O S.E. Gama, clube da cidade satélite de Gama disputou a série A até 2002 e a série B até 2008 . O outro time do Distrito Federal que teve destaque no cenário do futebol foi o Brasiliense F.C., da cidade satélite de Taguatinga, que conseguiu chegar na final da Copa do Brasil de 2002, perdida para o S.C. Corinthians Paulista.

${ }^{3}$ Empresa estatal responsável pelo loteamento e desenvolvimento imobiliário de Brasília. 
papel. Mesma situação ocorrida com a proposição de um túnel subterrâneo, abaixo do eixo monumental, que ligaria o subsolo do Mané Garrincha até o Centro de Centro de Convenções Ulysses Guimarães ${ }^{4}$ e a instalação de painéis solares na cobertura circular do estádio ${ }^{5}$ afim de garantir a pontuação do selo Leed que os promotores gostariam de obter nesta obra.

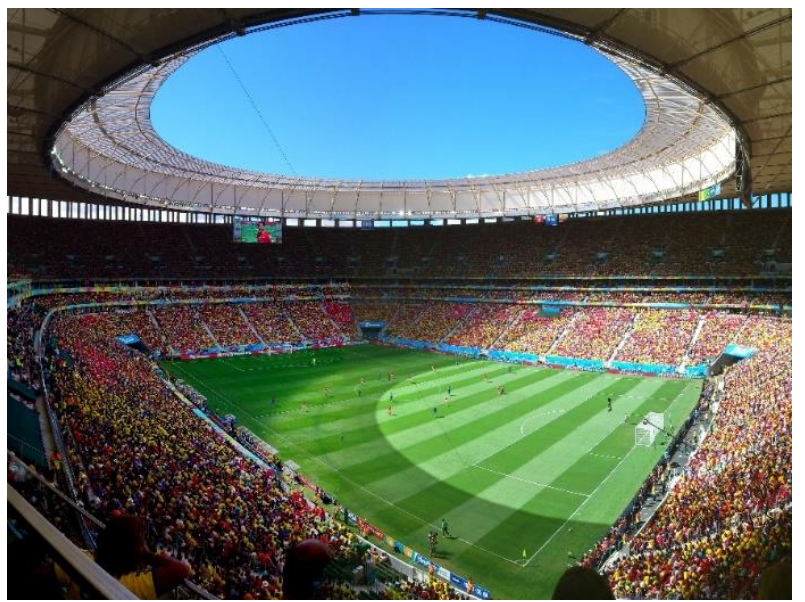

Figura 12: Vista interna do Estádio Mané Garrincha, em Brasília. Fonte: Acervo de Thiago Pelakauskas, 2014.

Inaugurado em 2013, como o estádio de abertura do evento teste para a Copa do Mundo, a Copa das Confederações em 2013 e utilizado tanto na Copa do Mundo de 2014 e nos Jogos Olímpicos de $2016^{6}$, o estádio teve o seu custo estimado em $\mathrm{R} \$ 1,8$ Bilhões (considerando a obra do próprio estádio e obras para melhorias viárias em seu entorno), com uma estimativa de manutenção anual de R \$ 13 milhões, acabou se tornando um dos estádios mais caros construídos para o evento. Muito se questionou, por parte da opinião pública, a respeito da necessidade da cidade de Brasília ter um estádio desta magnitude, uma vez que a realização de partidas de futebol na cidade não era o evento mais comum e não havia demanda de público para encher o estádio. O poder público local almejava receber a partida inaugural da Copa do Mundo, e todos os esforços neste sentido foram aplicados tendo em vista as declarações acima colocadas. É notório o quanto as cidades acabam utilizando o city marketing a ponto de tentarem conseguir obter a atenção no cenário internacional das metrópoles, através da realização de obras de magnitude como esta, no caso o estádio Mané Garrincha. Essa relação do objeto, por parte do governo local, em ter um ícone pode ser apontado conforme Richard Scoffier coloca:

\footnotetext{
“A arquitetura não escapa dessa regra, inúmeros projetos tendem a transformar a construção funcional em objeto que objeta: primeiramente adaptando o procedimento inventado por Duchamp, ampliando o tamanho de um objeto qualquer, em seguida, considerando o edifício como um volume neutro que nada revela de sua fabricação, nem de sua função e, enfim, conferindo-lhe um inconsciente e invertendo a relação que o subordina aos seus usuários.” (2000, p. 169)
}

Atualmente o estádio encontra se em momento de indefinição em relação ao seu destino final. Desde 2016 o governo local tenta realizar "ceder" o estádio Mané Garrincha à iniciativa privada, através dos processos de concorrência em estudos técnicos de viabilidade. Para este processo, o

\footnotetext{
${ }^{4}$ Este túnel, orçado em R\$ 287 milhões, acabou sendo executado parcialmente, sendo que o mesmo termina dentro do lote do estádio ligando o segundo subsolo até a área de estacionamento externo.

${ }^{5} \mathrm{O}$ custo orçado para a realização deste serviço era de $\mathrm{R} \$ 15$ milhões.

${ }^{6} \mathrm{Na}$ Copa do Mundo de 2014, o estádio de Brasília recebeu 7 partidas, incluindo a decisão de $3^{\circ}$ lugar. Já nos Jogos Olímpicos de 2016 acabou sendo uma das cidades sedes que recebeu as partidas de futebol masculino e feminino do evento.
} 
GDF denominou o conjunto poliesportivo que contém o estádio Mané Garrincha, o ginásio Nilson Nelson e o conjunto aquático Cláudio Coutinho como "Arenaplex". Nome este, que denota a necessidade de modificar os nomes de equipamentos públicos existentes para um nome que remete aos modismos internacionais da substituição de expressão "estádio" para "arena". O edital do processo foi revisto em 2018 e para atrair o mercado privado, o governo local informou que o custo do IPTU seria pago pelo mesmo. Segundo o GDF houveram interessados e em destaque o consórcio Arena BSB formado pelas empresas estrangeiras RNGD e Amsterdan Arena, além da Capital Live (Braço da WTorre) ${ }^{7}$ que pretende transformar o estádio Mané Garrincha em uma casa de shows de grande porte, tanto nacionais quanto internacionais. Outro item que acabou chamando a atenção da mídia local em relação à esta revisão do edital desta concorrência de privatização do estádio é a possibilidade do grupo ou empresa ganhadora do processo poder construir na área externa, entre o estádio e o autódromo um "bulevar" que poderia abrigar um programa de restaurantes, bares, casas noturnas, cinema e teatro, que conforme coloca Júlio César Reis (Presidente da Terracap) seria um "grande ponto de encontro, uma nova referência na região central da capital" (2018).

Portanto, mesmo com a realização esporádica de partidas de futebol, principalmente de times de futebol cariocas e mineiros, e também com a realização de shows internacionais e nacionais, o equilíbrio financeiro entre os custos de manutenção, operação e a obtenção de receitas com estes eventos não acaba fechando a conta. Retomando o discurso de Mário Henrique Lima, no que tange as expectativas de retorno do estádio Mané Garrincha em relação ao seu legado, ele aponta: "Nós não esperávamos e ninguém deve esperar o retorno de R\$ 1,4 Bilhões" (Lima, 2016) ${ }^{8}$. Uma pena, tendo em vista os valores e recursos públicos empregados nesta obra. Por fim, até o momento não há uma decisão sobre qual será o destino do estádio, se de fato será privatizado ou será utilizado para outro fim, porém a única certeza é que a conta a ser paga pela construção deste equipamento ainda demorará para se equalizar e trazer algum retorno de ordem sócio urbanística para Brasília.

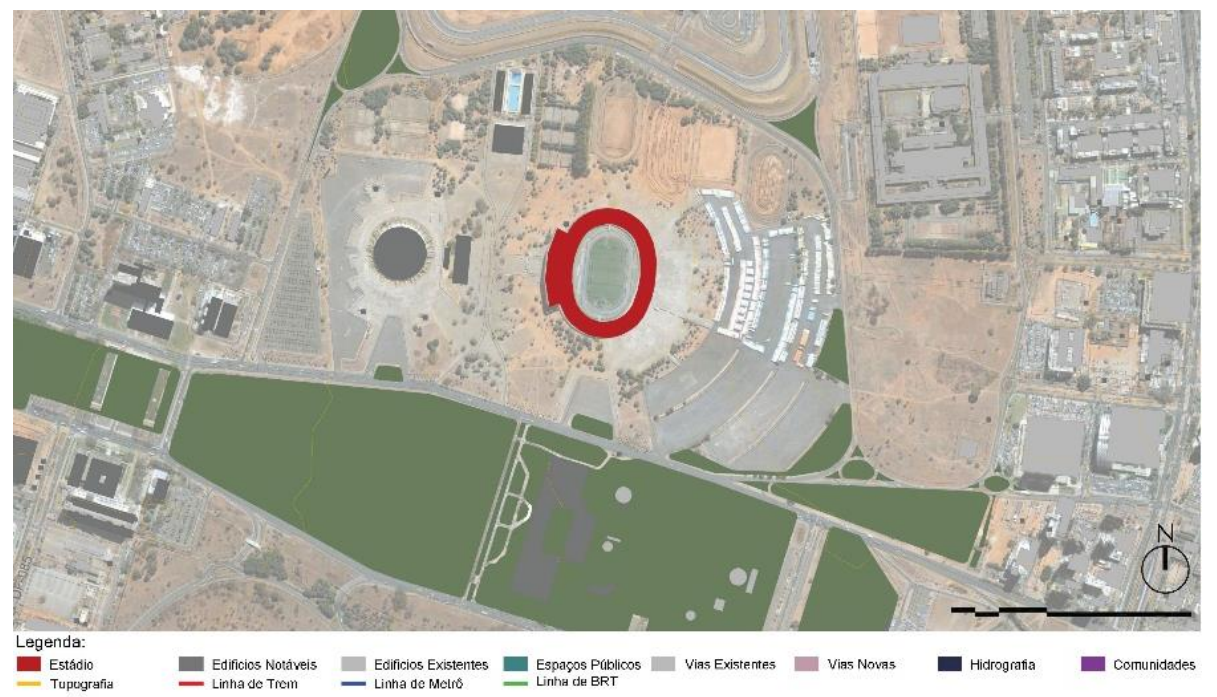

Figura 13: Mapa Urbano do entorno urbano do Estádio Mané Garrincha, em Brasília, em 2010.

Fonte: Elaborado pelo autor, com base no projeto de Castro Mello Arquitetos e base cartográfica Google Earth. 2018.

\footnotetext{
${ }^{7}$ Conforme apontado em matéria jornalística do site Metrópoles (25/03/2018).

${ }^{8}$ Conforme apontado em matéria jornalística do site G1 - Globo (09/07/2016).
} 


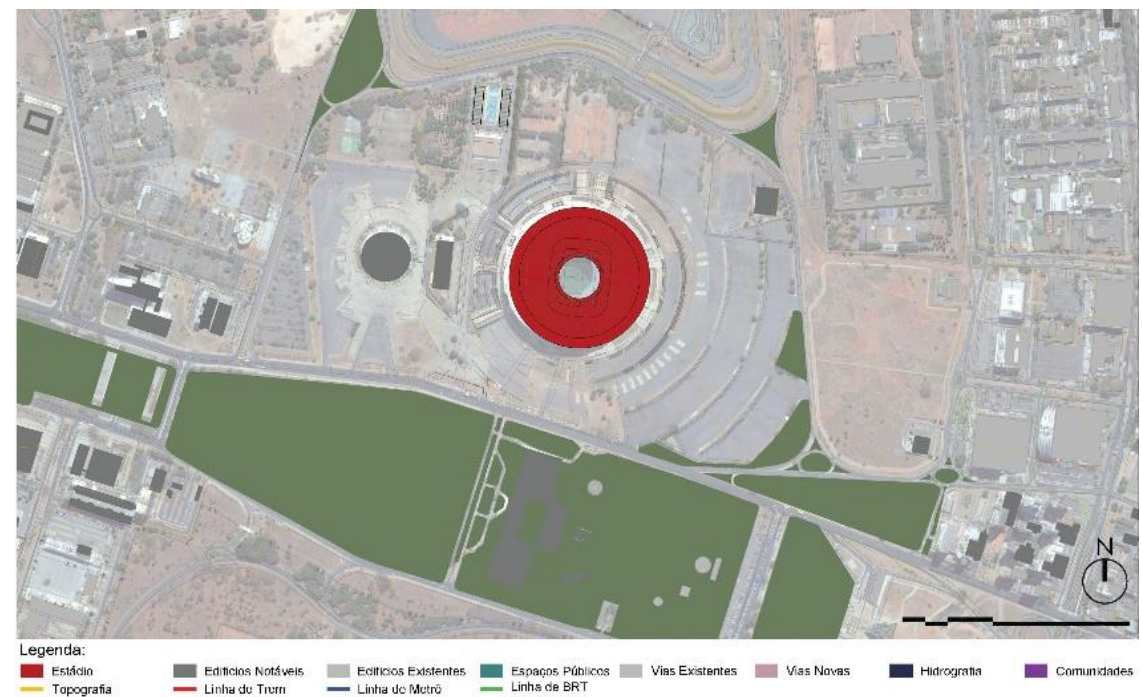

Figura 14: Mapa Urbano do entorno urbano do Estádio Mané Garrincha, em Brasília, em 2014.

Fonte: Elaborado pelo autor, com base no projeto de Castro Mello Arquitetos e base cartográfica Google Earth, 2018.

\subsection{Arena Pernambuco, Recife}

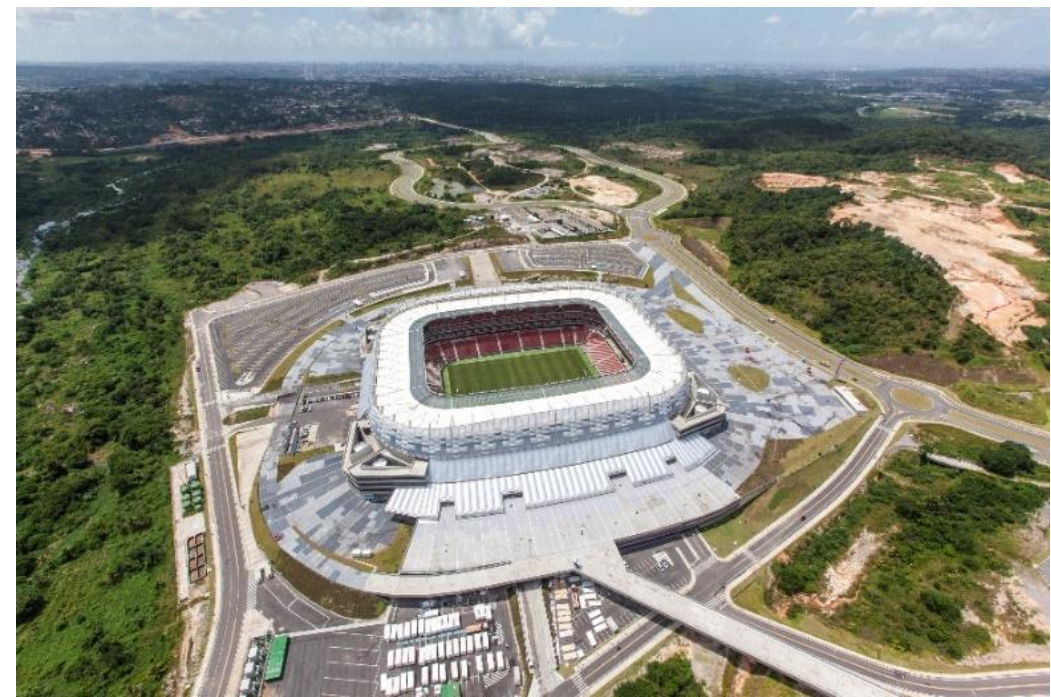

Figura 15: Vista aérea da Arena Pernambuco, na região metropolitana de Recife.

Fonte: Portal Copa 2014, Foto de Ana Araújo / Faquini Produção Fotográfica, 2014.

Escolhida como uma das cidades sedes da Copa do Mundo de 2014, representando a região nordeste e sediando o evento novamente, uma vez que recebeu uma das partidas da Copa do Mundo de 1950, a cidade de Recife já contava em sua trama urbana com três estádios particulares para seus respectivos clubes: a Ilha do Retiro, casa do Sport; o estádio dos Aflitos, casa do Náutico e por fim o estádio do Arruda, casa do Santa Cruz. Além do fato de que estes estádios já possuíam a conexão e a identificação com o bairro presente em seu respectivo entorno. No entanto, os poderes públicos da cidade, decidiram que para a realização da Copa das Confederações 2013 (Evento Testes) e para a Copa do Mundo de 2014 era necessário construir um novo estádio que estivesse apto e atendendo as especificações e requerimentos da FIFA. Para isto acabou sendo escolhida uma área, na região metropolitana de Recife, especificamente em São Lourenço da Mata, para a instalação deste novo estádio. 
Localizado a $23 \mathrm{~km}$ da capital, as margens da rodovia BR-408 e entre o rio Capibaribe e São Lourenço da Mata, este projeto foi chamado por seus promotores como a "Cidade da Copa". O projeto da Cidade da Copa desenvolvido pelo escritório inglês AECOM, trazia o conceito de smart cities ou cidades inteligentes e contemplava além do estádio, a criação de um novo bairro na cidade, dotado de novos empreendimentos imobiliários tais como: edifícios residenciais, empresariais, de serviços, institucionais, um hotel e um novo shopping. Portanto, configura se aqui a tentativa de crescimento urbano, um espraiamento horizontal do tecido metropolitano, utilizando o estádio como um elemento indutor de transformação e captação de investidores e recursos para a ocupação deste novo bairro. Planejamento urbano aliado aos interesses de empresas de capital privado, tais como empreiteiras e incorporadores imobiliários, que acaba se caracterizando como Rolnik aponta:

\begin{abstract}
"A constituição de um território recortado do conjunto da cidade, construído e controlado sob a lógica da extração de renda e da promoção do consumo, gerido de forma paralela à gestão geral da cidade, expande-se assim dos "enclaves" residenciais e comerciais - como condomínios fechados e shopping centers - em direção a pedaços inteiros de cidade. Desse modo, atores privados passam a ter também exercício de governo, ampliando, portanto, a zona de indefinição entre o privado e o público e reconfigurando a ordem política.” $(2015$, p. 385)
\end{abstract}

Implantado semelhante ao caso do Allianz Arena, em Munique e AT\&T Stadium, no Texas, onde o estádio encontra-se "ilhado" por um grande parque de estacionamento de veículos e paralelo às principais rodovias e estradas, o edifício acaba se tornando uma peça de marketing, um outdoor para que grandes indústrias e companhias possam anunciar os seus produtos e as suas marcas. A Arena Pernambuco, conforme o autor Lourival Lopes Costa Filho (2016) aponta, teve um contrato de naming rights assinado com o Grupo Petropólis, dono da marca de bebidas Itaipava e TNT Energy Drink, em um contrato de R \$ 100 milhões, durante um período de 10 anos, renomeando o estádio para "Itaipava Arena Pernambuco", onde se previa a exclusividade na comercialização destas bebidas nos bares e restaurantes do estádio, "além de $100 \%$ do espaço publicitário de suas áreas externas e 60\% de suas áreas internas” (FILHO, 2016, p.311).

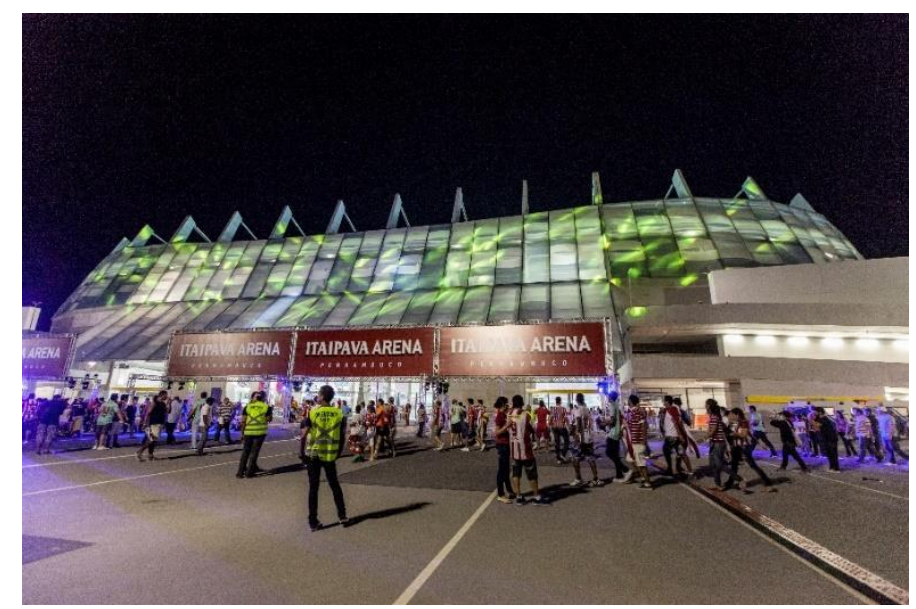

Figura 16: Vista externa da Arena Pernambuco, na região metropolitana de Recife. Fonte: Portal Copa 2014, Foto de Ana Araújo, 2013.

O projeto arquitetônico do estádio tem a autoria do escritório Fernandes Arquitetos Associados, que em paralelo havia realizado o atual projeto de reforma do estádio do Maracanã. A obra foi realizado pela construtora Odebrecht e teve o seu custo de construção estimado em R \$ 532 milhões ${ }^{9}$. Em seu interior o estádio apresentava a sua planta retangular com as suas arestas curvas,

\footnotetext{
${ }^{9}$ Conforme apontado em matéria jornalística do site BBC (12/06/2017).
} 
sendo dividido em quatro níveis de arquibancada nos setores Oeste e Leste e dois níveis de arquibancada nos setores Norte e Sul. Com uma arquibancada próxima ao campo de jogo, concebido para receber partidas de futebol e shows, em corte o estádio apresenta uma ótima curva de visibilidade ao espectador. O restante de seu programa se resume a camarotes e cabines de imprensa nos níveis intermediários, bares e sanitários posicionados nos quatro setores do estádio dedicados ao público geral, nos níveis da arquibancada superior e inferior. Em seu subsolo encontra se toda a parte operacional para os atletas, vestiários, salas de conferência, além da área trabalho para imprensa e estacionamento para veículos credenciados.

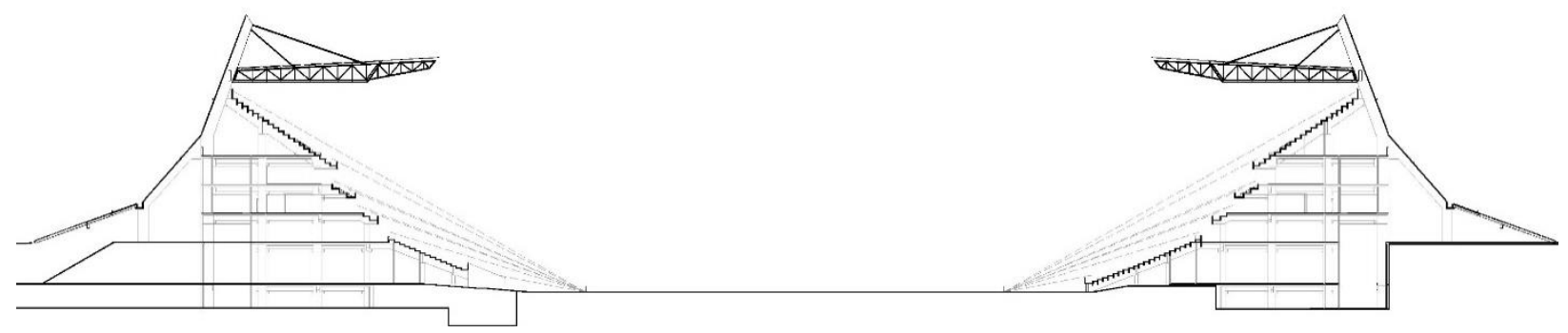

Figura 17: Corte Transversal esquemático da Arena Pernambuco.

Fonte: Elaborado pelo autor com base no projeto de Fernandes Arquitetos Associados, 2018.

Tratando do seu exterior, a cobertura do estádio possui uma configuração diferenciada dos demais estádios construídos no Brasil para a Copa do Mundo: a sua concepção demonstra a tentativa de demonstrar que a cobertura "nasce", através de um desenho de piso, do nível térreo e com inclinações diferenciadas sobre a estrutura do edifício, se desenvolve até chegar e terminar sobre as arquibancadas do estádio. O estádio possui dois parques de estacionamentos localizados respectivamente no setor leste e ao setor oeste, sendo que este último por estar mais afastado do estádio, isolado por uma via de veículos, possui uma passarela até acesso até o platô de acesso ao estádio. Do projeto da Cidade da Copa, somente foi construído além do estádio, o anel viário interno do novo bairro, via denominada como Ramal Arena Pernambuco, que acaba conectando a gleba até Loteamento pré existente de Santo Cosme e Damião, onde foi construída a estação de metrô Cosme e Damião, distante e quase $2 \mathrm{~km}$ do estádio, cuja linha tem como pontos finais a estação Camaragibe e a estação Recife, no centro da cidade.

Portanto, desta maneira, acaba evidenciado a estratégia adotada, por seus promotores, no desenvolvimento do masterplan referente a localização final da Arena Pernambuco na Cidade da Copa. Para efeitos de deslocação da massa de espectadores e torcedores, um estádio estar mais próximo do sistema público de transportes, seria muito mais lógico e interessante para até mesmo o desenvolvimento local dos bairros pré-existentes, contudo os promotores, acabaram privilegiando o sistema automotivo e as potencialidades que um estádio, funcionando como outdoor, as margens da rodovia BR 408 poderia trazer como contrapartida de obtenção de receitas quanto imagem simbólica de um novo ícone arquitetônico metropolitano. Essa decisão estratégica acabou trazendo consequências negativas para a tentativa de desenvolvimento do projeto da Cidade da Copa como um todo. A começar pelo estádio, conforme aponta a matéria jornalística ${ }^{10}$, a Arena Pernambuco tem dado prejuízo para os cofres públicos e seus administradores, aponto de que a primeira empresa a ter assumido a gestão do estádio (via PPP) logo após a realização da Copa do Mundo, a Odebrecht acabou desistindo e anunciou a sua saída do empreendimento, assim como o patrocínio com o Grupo Petrópolis também acabou sendo encerrado.

\footnotetext{
${ }^{10}$ A respeito do atual status da Cidade da Copa e da Arena Pernambuco. Conforme apontado em matéria jornalística do site Folha PE (06/08/2017).
} 


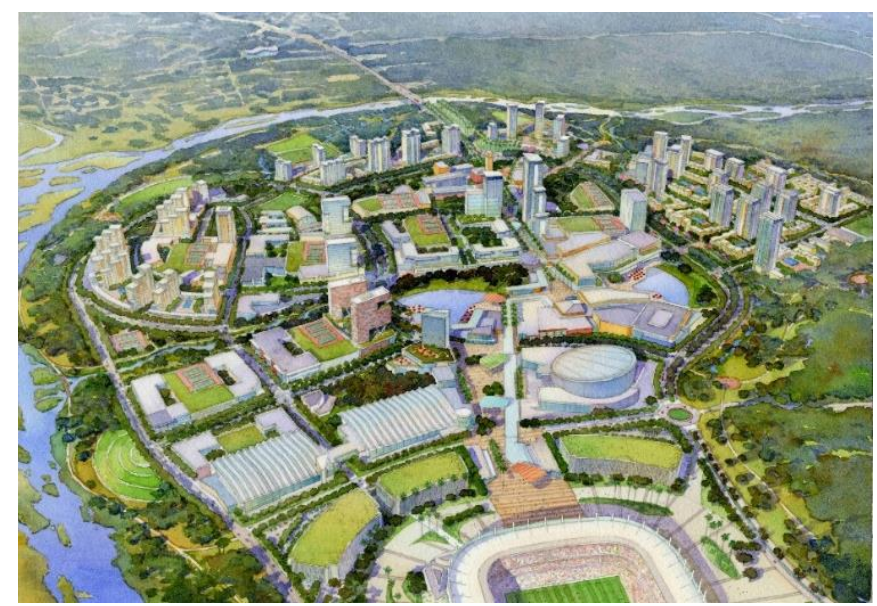

Figura 18: Perspectiva do projeto da Cidade da Copa na região metropolitana de Recife.

Fonte: Jornal Lance, 2012, Projeto da AECOM.

Devido à distância entre a capital da cidade e a região do estádio, muitos torcedores não têm ido aos poucos jogos de futebol que esporadicamente são realizados na Arena Pernambuco. Uma vez que, como todos os times de Recife já possuem um estádio próprio e que os mesmos já possuem uma conexão e identidade com os seus respectivos bairros e entorno, faz com que o torcedor acabe optando por só assistir a jogos realizados na capital, levando em conta também, o fácil deslocamento e o sistema de transporte público que o mesmo pode ter em relação a estes estádios em Recife. Conforme aponta Dirceu Rodolfo (2017), conselheiro do TCE em matéria jornalística ${ }^{11}$ :

\footnotetext{
"Este é um empreendimento muito custoso, pois tem manutenção cara e depende dos jogos para ter receita. E, como os grandes clubes pernambucanos têm seus próprios estádios, é difícil imaginar um fluxo de jogos suficiente para manter os investimentos. É uma equação difícil de fechar. Então, não sei se este é um negócio sustentável para um investidor de fora"
}

Diversos tipos de eventos alternativos, de ordem ludo esportivos e culturais, têm sido realizados dentro e fora da Arena Pernambuco para que o estádio não fique ocioso e sem uso em dias de não jogos. Assim coloca a Secretaria de Esportes do governo de Pernambuco, em matéria jornalística da BBC ${ }^{12}$ :

\footnotetext{
“A Arena de Pernambuco, em 12 meses, sediou mais eventos do que no período de gestão privada. De junho de 2016 a junho de 2017, foram 71 eventos de caráter multiuso, desde shows, passando por reuniões comerciais, eventos corporativos de empresas, confraternizações, entre outros" (2017)
}

Mesmo a Cidade da Copa ter sido planejada para ser executada em fases durante 25 anos, as informações da mídia local demonstram que o atraso ocorrido na execução dos demais equipamentos do empreendimento, se deve ao fato de que mediante este contexto, o mercado privado e investidores acabam por sua vez perdendo o interesse neste projeto além de que as glebas do empreendimento ainda necessitam da aprovação da Agência Estadual de Meio Ambiente local para que se possa iniciar qualquer atividade nos terrenos em questão. Ou seja, o que acaba se tornando evidência "é uma situação de planejamento estratégico falho e insuficiente frente às demandas discursivas de projeto urbano que justificaram as obras da Arena, mas que não foram executadas e seguem sem previsão de o serem" (ABBAMONTE, PELAKAUSKAS, CURITIBA;

\footnotetext{
${ }^{11}$ Idem.

12 Ibidem a 9.
} 
2017). Enquanto a solução para o problema não é encontrado, a Arena Pernambuco agora está sendo administrada e gerida pela Secretaria de Esportes, Turismo e Lazer do Estado.

Apesar deste órgão ter conseguido reduzir a custo mensal de manutenção de $\mathrm{R} \$ 2$ milhões para $\mathrm{R} \$$ 840 mil, conforme aponta a matéria do jornal Folha PE (06/08/17), o retorno à população local tem sido muito pouco enquanto equipamento público e muito caro enquanto gasto em sua gestão e manutenção. Além de não ter conseguido atrair grandes shows do circuito mainstream nacional e internacional, o estádio têm recebido poucas partidas de futebol, em média de três a cinco jogos por mês com uma média de público muito abaixo da capacidade total. Pelo fato de não ter sido construído mais nenhum edifício, além do próprio estádio, a ausência de vida e movimento de pessoas, faz com que a região da Arena Pernambuco seja um lugar perigoso durante o período noturno, uma vez que o local só conta com o sistema viário construído e com a vegetação nativa até o presente momento.

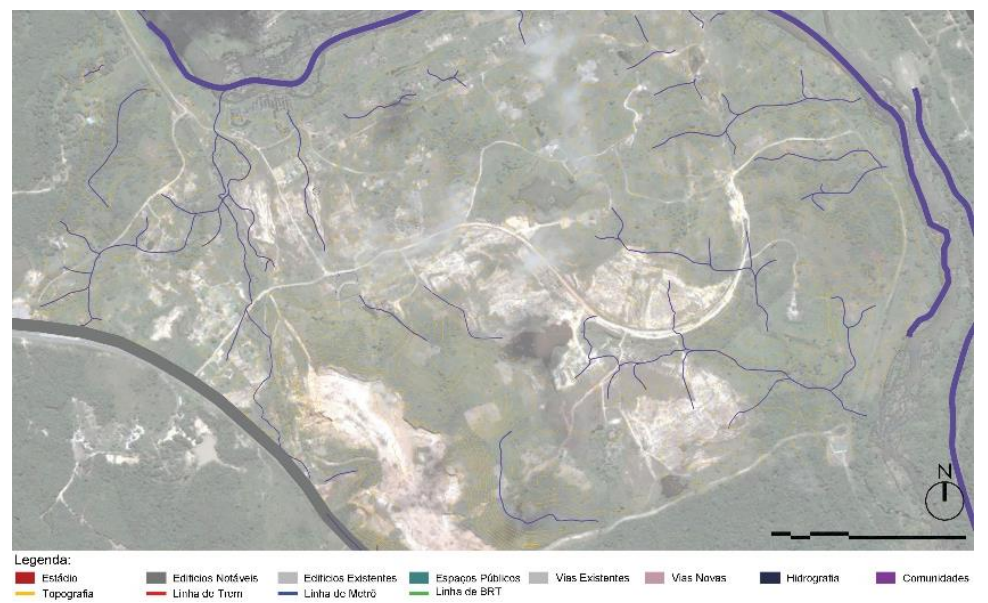

Figura 19: Mapa Urbano da gleba do projeto Cidade da Copa, em Recife, em 2010.

Fonte: Elaborado pelo autor, com base no projeto de Fernandes Arquitetos Associados e base cartográfica Google Earth., 2018.

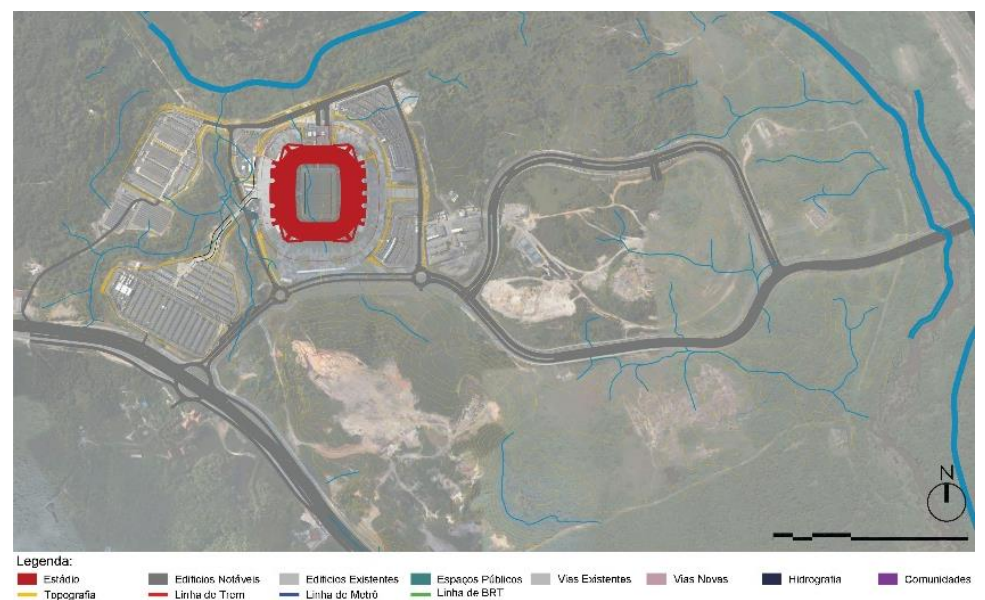

Figura 20: Mapa Urbano da gleba do projeto Cidade da Copa, em Recife, em 2014.

Fonte: Elaborado pelo autor, com base no projeto de Fernandes Arquitetos Associados e base cartográfica Google Earth, 2018.

\section{CONSIDERAÇÕES FINAIS}

Os três exemplos acima analisados, expressam e sintetizam cada um a sua maneira o que foi a realização do evento da Copa do Mundo no Brasil em 2014. Enquanto no caso curitibano, com a 
Arena da Baixada, tivemos uma situação de risco em que o estádio teve a sua construção "finalizada" às vésperas do evento, em Brasília e em Recife, apesar destes estádios terem sido inaugurados praticamente na realização do evento teste da Copa das Confederações, em 2013, alguns sintomas da falta de planejamento estratégico por parte de seus promotores já se apresentavam.

A falta de um gestor capaz de capitar diversas atividades, para muito além do jogo de futebol propriamente dito, fez com que os estádios de Brasília e de Recife gerassem mais déficit do que superávit, tendo em vista a pouca procura por parte de clubes e federações em realizar as suas partidas nestes estádios aliado ao fato de que, no caso brasiliense o estádio foi construído para uma capacidade de público acima do que a cidade necessitava e no caso pernambucano ter a construção de um novo estádio fora da região metropolitana em uma cidade em que seus três principais clubes já contavam com estádios próprios.

Enquanto no caso curitibano, o clube do Atlético Paranaense, teve que arcar com os seus custos da reforma e ampliação da obra, devido ao fato do estádio ser propriedade particular do clube, portanto assumindo o ônus e o bônus da situação, fez com que a cidade de Curitiba não sofresse diretamente os custos de ter um equipamento subutilizado, pelo contrário, a Arena da Baixada, conforme colocado anteriormente, além de realizar as partidas de futebol do clube também acaba realizando outros tipos de eventos para a obtenção de receita para a própria manutenção do estádio. Urbanisticamente falando, o estádio encontrasse atualmente inserido em uma malha urbana adensada, cercado por edifícios residenciais e comerciais, tendo a presença da praça Afonso Botelho, como uma extensão urbana de seus espaços internos e desta maneira sendo um equipamento que consegue respirar e viver a cidade.

Em posição antagônico ao caso curitibano, o estádio Mané Garrincha em Brasília, apesar de possuir um projeto com desempenho arquitetônico satisfatório e conforto ao usuário dos espaços internos do estádio conforme as especificações da FIFA, acaba por sua vez em sua área externa, fragilizado urbanisticamente em função do abandono e falta de planejamento por parte dos órgãos públicos no que se refere à criação de espaços públicos de qualidade voltados à população local. Dotado de uma ampla área externa o conjunto poliesportivo em que se encontra o estádio Mané Garrincha, possuía um projeto paisagístico que por sua vez poderia suprir ou amenizar o seu atual entorno seco e árido, ausente da presença de pessoas e somente receptivo aos automóveis que transitam pelo eixo monumental e vias adjacentes. Apesar de realizar alguns festivais musicais e shows em sua área externa, isto acaba sendo um retorno muito abaixo do que era esperado pelo custo que envolveu esta obra e o quanto este equipamento poderia oferecer de retorno sócio esportivo para a população local.

E por fim, o plano da Cidade da Copa, acaba por sua vez sacramentando a falta de planejamento por parte das entidades promotoras e do poder público no que se refere as estratégias de expansão e desenvolvimento urbano na cidade de Recife. Seduzido pelas imagens e simbolismos produzidos no cenário da arquitetura contemporânea internacional, o star system arquitetônico, a construção de um estádio - outdoor como função secundária - não acabou surtindo o efeito esperado, como ícone arquitetônico regional e muito menos como elemento indutor de transformação e desenvolvimento local. Infelizmente localizado atualmente longe da capital, a $23 \mathrm{~km}$, carece de uma melhor infraestrutura de sistema de transporte público e de espaços públicos que possam se tornar áreas para atividades de lazer e entretenimento da comunidade presente em seu entorno. $\mathrm{O}$ seu posicionamento final no masterplan da Cidade da Copa, acabou determinando o seu próprio isolamento no empreendimento, fazendo com que este estádio se tornasse mais um dos que resultaram, até o presente momento, em insucesso enquanto produção de espaço urbano de qualidade. 


\section{REFERÊNCIAS}

ABBAMONTE, Luciano, PELAKAUSKAS, Thiago, CURITIBA, Julio. Arquiteturas do espetáculo em áreas periféricas: os casos da Arena Corinthians e Arena Pernambuco, Brasil. Disponível em: http://anpur.org.br/xviienanpur/principal/publicacoes/XVII.ENANPUR_Anais/ST_Sessoes_Tem aticas/ST\%203/ST\%203.13/ST\%203.13-13.pdf Acesso em 22. Jan. 2018.

ARANTES, Otília. Uma estratégia fatal. A cultura nas novas gestões urbanas. In: ARANTES, Otília, VAINER, Carlos, MARICATO, Ermínia. A cidade do pensamento único: desmanchando consensos. Petrópolis, RJ: Vozes, 2000.

ASCHER, François. Os novos princípios do urbanismo. São Paulo: Romano Guerra, 2010.

BARBOSA, Marina. Os problemas da arena de Pernambuco. Disponível em: https://www.folhape.com.br/economia/economia/mercado/2017/08/06/NWS,37004,10,603,ECO NOMIA,2373-OS-PROBLEMAS-ARENA-PERNAMBUCO.aspx. Acesso em 05. Jun. 2018.

BROUDEHOUX, Anne Marie. A construção da imagem urbana orientada por grandes eventos: potemkinismo, a mídia e a periferia. In: SÁNCHEZ, Fernanda, BIENENSTEIN, Glauco, OLIVEIRA, Fabrício Leal de, NOVAIS, Pedro. A copa do mundo e as cidades: políticas, projetos e resistências. Rio de Janeiro: Editora da UFF, p. 19-34, 2014.

BURLA, Léo. São Lourenço da Mata 'ganha' estádio da copa e vê números explodirem. Disponível em: https://www.lance.com.br/todos-esportes/sao-lourenco-mata-ganha-estadio-copanumeros-explodirem.html. Acesso em 05. Jun. 2018.

CALLIARI, Mauro. Arena da Baixada: o melhor estádio do Brasil combina futebol e urbanidade. Disponível em: http://vitruvius.com.br/revistas/read/projetos/17.195/6477. Acesso em 03. Jun. 2018.

COSTA FILHO, Lourival Lopes. Megaeventos, Design e Paisagem Urbana. In: Ricardo Alexandre Paiva. (Org.). Megaeventos e intervenções urbanas. 1ed. Barueri: Manole, v. 1, p. 305324, 2017.

DEBORD, GUY. A sociedade do espetáculo. Rio de Janeiro: Contraponto Editora, 1997.

FERRAZ, Ian. Único interessado no Mané Garrincha quer transformá-lo em casa de show. Disponível em: https://www.metropoles.com/distrito-federal/unico-interessado-no-manegarrincha-quer-transforma-lo-em-casa-de-show. Acesso em 04. Jun. 2018.

FIFA - Fédération Internationale de Football Association. 2011. Football Stadiums -

Technical recommendations and requirements. Zurich: Fédération Internationale de Football Association.

GAZETA do povo. Aprovados? Veja as notas recebidas pelos estádios paranaenses. Disponível em: http://www.gazetadopovo.com.br/esportes/futebol/campeonatoparanaense/aprovados-veja-as-notas-recebidas-pelos-estadios-paranaenses-

15q7hwd46307kl2v6byjaoeeo. Acesso em 04. Jun. 2018.

HARVEY, David. A produção capitalista do espaço. São Paulo: Annalbume, 2005. 
MEYER, Regina Maria Prosperi. Atributos da metrópole moderna. São Paulo: Editora Perspectiva, vol.14, no 4, p.3- 9, 2000.

MENDONÇA, Renata. Três anos após início da Copa, 'elefantes brancos' servem até de escola para reduzir prejuízo. Disponível em: http://www.bbc.com/portuguese/brasil-40226673. Acesso em: 05. Mai. 2018.

MONGIN, Olivier. A condição urbana: a cidade na era da globalização. São Paulo: Estação Liberdade, 2009.

MUÑOZ, Francesc. Urbanalización: paisajes comunes, lugares globales. Barcelona: Editorial Gustavo Gili, 2010.

PORTAL da copa 2014. Disponível em: www.copa2014.gov.br. Acesso em 05. Mai. 2018.

RODRIGUES, Mateus. GDF deve ceder Mané Garrincha ao setor privado com projeto inacabado. Disponível em: http://g1.globo.com/distrito-federal/noticia/2016/07/gdf-deve-cedermane-garrincha-ao-setor-privado-com-projeto-inacabado.html. Acesso em 04. Jun. 2018.

ROLNIK, Raquel. Guerra dos lugares: a colonização da terra e da moradia na era das finanças. São Paulo: Editora Boitempo, 2015.

ROLNIK, Raquel. O espetáculo e o mito. Disponível em: http://pagina22.com.br/2011/08/09/oespetaculo-do-mito/. Acesso em 22. Jan. 2018.

SALGADO, Diego, CASTRO, Felipe. Arenas do Brasil: Arquitetura e engenharia nos estádios brasileiros para a copa de 2014. São Paulo: Mandarim Comunicação, 2014.

SANTOS, Milton. A pobreza urbana. São Paulo, Recife: Editora Hucitec, 1978.

SANTOS, Milton. Por uma nova globalização: do pensamento único à consciência universal. Rio de Janeiro: Editora Record, 2001.

SCOFFIER, Richard. Os quatro conceitos fundamentais da arquitetura contemporânea. In: OLIVEIRA, Beatriz Santos de. Leituras em teoria da arquitetura, vol 1 - coleção PROARQ. Rio de Janeiro: Viana \& Mosley, 2009.

SOLÀ-MORALES, Manuel. Cosas urbanas. Barcelona: Editorial Gustavo Gili, SL, 2008

WILHEIM, Jorge. São Paulo e seus pontos de encontro. Revista Acrópole, n. 295, São Paulo, p. 223-37. Disponível em: http://www.acropole.fau.usp.br/edicao/297. Acesso em: 23.Mai.2018

WISNIK, Guilherme. Ensaio crítico: à deriva nas cidades. 1ª ed. São Paulo: Publifolha, 2009. 